\title{
Publikacje edukacyjne wydawnictwa Ludwika Fiszera do I wojny światowej
}

\begin{abstract}
Bez historii księgarstwa historia kultury byłaby niepełna, bez działalności energicznych, ambitnych, światłych księgarzy-wydawców nie podobna wyobrazić sobie ruchu wydawniczego'.
\end{abstract}

Przez wieki Łódź była maleńkim rolniczym miasteczkiem, zapleczem dla okolicznych rolników. Tutaj odbywały się targi, jarmarki, tu pracowali nieliczni rzemieślnicy. Dopiero koniec XIX wieku stał się początkiem niespotykanej gdzie indziej dynamiki rozwoju miasta. Monokultura przemysłowa (głównie włókiennictwo) sprawiła, że o Łodzi końca XIX wieku zwykło się mówić „polski Manchester”.

Łódź w okresie Królestwa Polskiego obok dynamicznie rozwijającego się przemysłu posiadała interesującą strukturę demograficzną. Według spisu powszechnego z 1864 r. na 38,1 tys. stałych mieszkańców - 14,775 tys. (38,7\%) to ludność narodowości polskiej, 15,810 tys. $(41,5 \%)$ to ludność niemiecka, 7,480 tys. $(19,6 \%)$ stanowili Żydzi, pozostała część $(0,2 \%)$ to obywatele innych wyznań i narodowości (m.in. Rosjanie, Francuzi, a nawet Hiszpanie).

Należy tutaj dodać, że to samo źródło określa $75 \%$ ludności miasta jako analfabetów². Zasadne więc będzie zauważyć, iż potrzeby czytelnicze ówczesnych mieszkańców miasta musiały być mocno ograniczone.

Podobnie kształtowały się potrzeby kulturalne. 3/4 mieszkańców Łodzi to robotnicy fabryk ówczesnych potentatów włókienniczych: Meyera, Poznańskiego, Scheiblera. 16-godzinny dzień ich pracy wyznaczał swoiste zainteresowania kulturalne. Wizyty w okolicznych szynkwasach i piwiarniach stanowiły najczęstszą rozrywkę. Dlatego zapewne pierwszy odnotowany w Łodzi w 1844 roku występ

* Dr, Uniwersytet Łódzki, Wydział Nauk o Wychowaniu, Katedra Historii Wychowania i Pedeutologii, 91-148 Łódź, ul. Pomorska 46/48.

1 J. Mlekicka, Jakub Mortkowicz - księgarz i wydawca, Wrocław 1974, s. 7.

2 W. Puś, Dzieje Łodzi przemysłowej, Łódź 1987, s. 70. 
zespołu teatralnego I. Marzantowicza zorganizowano w zajeździe na Starym Mieście, a odnosząca wielkie sukcesy krakowska trupa teatralna Józefa Fajfra, która odwiedziła Łódź dwukrotnie w 1858 roku, miejscem swoich występów uczyniła ogródek piwiarni przy ulicy Dzielnej (dziś Narutowicza) ${ }^{3}$.

By móc rozwijać potrzeby czytelniczo-kulturalne łodzian, należało więc przede wszystkim rozpocząć walkę z analfabetyzmem. A instytucji edukacyjnych w XIX-wiecznej Łodzi było niewiele. W 1863 roku istniało 9 elementarnych szkół rządowych, jedna 4-klasowa szkoła powiatowa realna i kilka szkół prywatnych. Wprawdzie w 1883 roku zanotowano w mieście już 16 szkół ludowych, ale ciągle dla ok. 1000 dzieci z danego rocznika nie było w nich miejsca ${ }^{4}$.

Powyższe rozważania mogą prowadzić do wniosku, że miasto Łódź w Królestwie Polskim było szczególnie trudnym rynkiem księgarskim.

Niewielkie potrzeby intelektualne mieszkańców wynikały nie tylko z przesłanek formalnych - braku umiejętności czytania i pisania, przeszkodą były także powody ekonomiczne. Bieda, a co za tym idzie niski poziom życia, znacznie ograniczały zapotrzebowanie na ambitniejsze książki nawet tych obywateli, którzy potrafiliby je przeczytać.

Jednak w tym wielonarodowym mieście, pozbawionym tradycji kulturalnych, firma księgarsko-wydawnicza Ludwika Fiszera położyła szczególne zasługi na niwie rozbudzania i upowszechniania potrzeb edukacyjnych mieszkańców, by z czasem stać się znaczącą instytucją oddziałującą na gusty czytelników na terenie całego Królestwa Polskiego.

Założyciel firmy Ludwik Fiszer senior urodził się 12 lutego 1844 roku w Łodzi.

Rodzina Fiszerów - ojciec Adam i matka Henrietta przybyli do Łodzi na początku lat 40. XIX wieku ze Strasburga. W 1851 roku kupili dom przy ul. Piotrkowskiej 47 i tym samym osiedlili się w Łodzi na stałe.

We wczesnym dzieciństwie Ludwika zmarł ojciec rodziny Adam, i chłopiec szybko musiał się usamodzielnić. Po ukończeniu w Łodzi 4-klasowej niemiecko-rosyjskiej szkoły, w wieku 12 lat wyjechał do Warszawy i tam rozpoczął 4-letnią praktykę księgarską w szanowanej firmie Michała Glucksberga. Po jej ukończeniu otrzymał tytuł czeladnika i stanowisko pomocnika księgarza. Praktykę księgarską kontynuował jeszcze przez kilka lat w Warszawie w innej znakomitej firmie księgarskiej - Sennewaldów. Równocześnie uczył się w szkole wieczorowej i ukończył kursy buchalterskie. Około roku 1882 powrócił do Łodzi i w niedługim czasie nabył od dawnego kolegi ze szkolnej ławy Cezarego Richtera księgarnię przy ulicy Piotrkowskiej $17^{5}$.

Tak rozpoczęła działalność firma księgarsko-wydawnicza, która przez 50 lat swego istnienia była jedną z największych księgarń w Królestwie Polskim, a w Łodzi stała się największą i najlepiej zorganizowaną firmą wydawniczą.

Przedsiębiorstwo księgarsko-wydawnicze, którego prawnym właścicielem w kwietniu 1882 roku stał się Ludwik Fiszer, mieściło się pierwotnie przy ul Piotr-

3 M. Z. Wojalski, Kieszonkowa kronika dziejów Łodzi, Łódź 1998, s. 18.

4 E. Podgórska, Szkolnictwo elementarne w Łodzi w latach 1808-1914, Łódź 1966, s. 92 i nast.

${ }^{5}$ Księgarnia Cezara Richtera, założona w 1872 roku, była pierwszą w Łodzi tego typu firmą, która od roku 1879 oprócz działalności sortymentowej rozpoczęła także działalność wydawniczą. 
kowskiej 17. Dwa lata później księgarnię przeniesiono do lokalu przy ul. Zawadzkiej 1 (dziś ul. Próchnika), by w roku 1896 umieścić ją ponownie, tym razem już na stałe, w obszernym lokum przy ul. Piotrkowskiej $48^{6}$.

Na początku działalności księgarnia prowadziła głównie sprzedaż literatury beletrystycznej w języku polskim i obcojęzycznej. Jednak by mogła utrzymać się na miejscowym rynku, musiała włączyć do swej oferty także sprzedaż artykułów szkolnych i materiałów biurowych.

Księgarnia w tamtym czasie stała się także swoistym ośrodkiem kulturotwórczym i edukacyjnym zarazem, prowadziła bowiem wypożyczalnię książek w kilku językach: polskim, niemieckim, angielskim, francuskimi i rosyjskim. Była to forma popularyzacji czytelnictwa z jednoczesną możliwością oddziaływania na czytelnicze gusta.

Ludwik Fiszer miał świadomość znaczenia propagowania czytelnictwa także wśród mniej zamożnej części mieszkańców miasta, a możliwość wypożyczania książek znacznie przybliżała biedniejszym mieszkańcom kontakt z literaturą.

Starał się także wśród mieszkańców miasta rozpowszechniać potrzebę czytania czasopism, bowiem księgarnia oferowała mieszkańcom Łodzi regularną prenumeratę prasy. Kulturotwórczą ideę kontynuował, podejmując próbę edycji przez rok (1899-1900) pierwszego w Łodzi czasopisma kulturalno-literackiego „Ognisko Rodzinne”. W zamyśle miało być to pismo popularne, przeznaczone dla tzw. klasy pracującej - łódzkich robotników. Pismo wyróżniała niezwykle staranna szata edytorska (strona graficzna, a także treści), również niska cena (15 kopiejek) miała sprzyjać zainteresowaniu nim mniej zamożnych. Jednakże trudno było zachęcić łodzian do jego nabywania - pismo wychodziło w ilości zaledwie 400 egzemplarzy i przynosiło stały deficyt ${ }^{7}$.

Księgarnia Fiszera, obok działalności sortymentowej, przejęła od poprzedniego właściciela, Cezarego Rychtera, także wydawnictwo. W 1889 roku nakładem oficyny wydawniczej „Ludwik Fiszer” ukazały się tłumaczenia Najpiękniejszych baśni H. Ch. Andersena oraz wydanego w 1899 r. Dziennika ucznia E. de Amicisa. Były to książki skierowane głównie do dzieci i młodzieży. Obok wymienionych, staraniem wydawnictwa ukazały się jeszcze: Skarb Sonory L. Bellemare'a, Syn marnotrawny i Prawda zawsze zwycięża F. Hoffmana oraz Mali Robinsoni Wielkiej Kartuzy J. Tauliera.

Obok książek dla dzieci rozpoczęto także druk podręczników szkolnych.

W latach 1889-1900 w księgarni wydano łącznie ponad 40 tytułów, podczas gdy nakład książek beletrystycznych wynosił ok. 3 tysięcy, to podręczników szkolnych dwa razy więcej (ok. 6 tysięcy) ${ }^{8}$.

Ludwik Fiszer senior zmarł w roku 1900 w wieku 56 lat. Zostawił dobrze prosperującą księgarnię swoim spadkobiercom - żonie Melanii i małoletnim jeszcze

${ }^{6}$ Księgarnia przeżyła jeszcze jedną przeprowadzkę, w 1918 roku spadkobiercy Ludwika Fiszera przenieśli firmę do domu rodzinnego przy ulicy Piotrkowskiej 47.

7 Śmierć L. Fiszera seniora zakończyła edycję pisma. Spadkobiercy odsprzedali tytuł nauczycielowi o nazwisku Thomas, który wraz ze swym bratem wydawał pismo jeszcze przez ok. dwa lata. W 1902 roku tytuł nabył Wiktor Czajewski, właściciel i redaktor łódzkiego czasopisma „Rozwój”.

8 J. Jaworska, Początki księgarstwa w Łodzi, „Roczniki Biblioteczne” 1969, nr 13, s. 124-125. 
wtedy sześciorgu dzieciom, w tym Ludwikowi juniorowi i Kazimierzowi - późniejszym księgarzom i kontynuatorom ojcowskiego dzieła ${ }^{9}$.

Melania Fiszerowa, osoba bardzo przedsiębiorcza, oddała zarządzanie firmą swemu bratu Pawłowi Miksie, który był długoletnim pracownikiem i uczniem jej męża, choć sama jako właścicielka szybko stała się pełnowartościowym partnerem brata. Podejmowała ważne decyzje w sprawach nie tylko handlowych, ale również pracowniczych. Brała czynny udział w prowadzeniu księgarni i dobieraniu wydawnictw, wpływając tym znacząco na jej charakter ${ }^{10}$.

Firma otworzyła sieć filii w podłódzkich miejscowościach, m.in. w Aleksandrowie i Wieluniu, również w Warszawie przy ul Długiej 20, później przy Bielańskiej $97^{11}$.

Księgarnia pod zarządem energicznej Melanii rozwinęła szereg form działalności. Przedmiotem handlu były wydawnictwa własne, ale także wydawnictwa firm, które księgarnia reprezentowała, m.in: Książnica Atlas (Lwów), E. Wende i s-ka (Warszawa), Wydawnictwo Polskie (Poznań), Zakład Narodowy im. Ossolińskich (Lwów).

Księgarnia rozszerzyła prenumeratę czasopism, które sprowadzano głównie z Lipska, a które cieszyły się ogromną popularnością wśród mieszkańców miasta. Przykładem niech będą pisma „Sonntagszeitung” czy „Die Woche”, które sprowadzano raz w tygodniu w ilościach 500-800 egzemplarzy ${ }^{12}$.

W księgarni można było kupić, obok książek w języku polskim, także wydawnictwa w językach francuskim, rosyjskim i niemieckim.

Odpowiadając na zapotrzebowanie społeczne, księgarnia posiadała w swojej ofercie także nuty, które nabywali bogaci mieszkańcy miasta, w domach których koncertowano, z modnymi wówczas tańcami salonowymi takich kompozytorów, jak F. Lehar, O Strauss, J. Fucik i in. Przede wszystkim jednak wydawnictwa te nabywały łódzkie zespoły rozrywkowe i towarzystwa muzyczne. Jak przystało na dobrą księgarnię, w ofercie był katalog nut oraz partytury druków muzycznych.

Nakładem księgarni ukazywała się również beletrystyka dla dorosłych oryginalna i tłumaczona, książki dla dzieci i młodzieży, poezje, publikacje pedagogiczne, popularnonaukowe, medyczne i słownikowe.

Około 1911 r. w ofercie księgarni Fiszera było 4276 tytułów z 24 grup tematycznych ${ }^{13}$.

9 Po śmierci matki, księgarnię przejął w 1922 r. najmłodszy syn Kazimierz Oskar Fiszer (1895-1943), który przed jej objęciem przeszedł solidne przygotowanie w warszawskiej księgarni swego starszego brata Ludwika.

10 Melania Fiszer bardzo dbała o swój personel. Osobiście każdego dnia przywoziła pracownikom podwieczorek.

Do chlubnych tradycji należało obdarowywanie pracowników premią z okazji świąt Bożego Narodzenia w wysokości 1-miesięcznej pensji wraz z prezentem w postaci twardo oprawionej książki, zaś w czasie wzmożonego ruchu przed rozpoczęciem roku szkolnego pracownikom wypłacano podwójną pensję.

11 Warszawską filię Melania Fiszer zlikwidowała w 1911 roku, by jej syn Ludwik Adam junior (1890-1962), po starannym przygotowaniu do zawodu najpierw na praktyce w rodzinnej firmie, potem za granicą, mógł kupić w Warszawie księgarnię „E. Wende i s-ka”, zaś swoje udziały odsprzedał rodzinie.

12 J. Krakowiak, Od Fiszera do „Pegaza”, Łódź 2005, s. 14.

13 Tamże, s. 27. 
Jednak nie literatura piękna okazała się specjalnością firmy. Księgarnia Ludwika Fiszera stała się słynna z edytowania wydawnictw podręcznikowych. Melania zrealizowała marzenie swego męża, bowiem księgarnia stała się najpoważniejszą firmą wydawniczą w Łodzi w tym zakresie.

Jeszcze za życia Ludwik Fiszer senior rozpoczął wydawanie podręczników do nauki języka niemieckiego w opracowaniu Augusta Kuhna i Henryka Zirklera, jak np. wydany w 1889 r. Deutsches Lesebuch mit Übungen zum Übersetzen, z tytułem dodatkowym w języku rosyjskim Niemieckaja kniga dla cztienija so statijami dla pieriewoda. Niebawem nawiązał kontakt $z$ łódzkimi nauczycielami: Władysławem Kokowskim i Kazimierzem Kędzierskim, którzy rozpoczęli opracowywać podręczniki do nauki języka polskiego.

W 1898 r. ukazały się dwa pierwsze podręczniki dla uczniów klas starszych - Władysława Kokowskiego Krótka etymologia języka polskiego i Krótka składnia języka polskiego łącznie z zasadami użycia znaków pisarskich, a dwa lata później podręcznik dla szkół elementarnych Kazimierza Kędzierskiego Mój elementarz, Cz. I ill.

Publikacje Władysława Kokowskiego stały się tematem obszernego artykułu pt. Łódź wydawnicza, zamieszczonego w lokalnym piśmie „Rozwój”, które z dumą odnotowało, że autorem publikacji jest obywatel „polskiego Manchesteru”, traktując ten fakt jako „nader przyjemną wiadomość”. Dwa podręczniki Kokowskiego poddano wnikliwej recenzji, w której podkreślano ich zalety: „krótka objętość, zwięzłe, jasne i dobitne definicje; przytoczenie wszystkich ważniejszych prawideł, objaśnionych umiejętnie dobranymi przykładami; nader trafny i systematyczny podział na części i rozdziały - wszystko to stanowi taką gramatykę, która przeciętnemu uczniowi raczej przeciętnemu człowiekowi na całe życie wystarczy" tak pisano o Etymologii, podobnie o Składni, która zawiera „wszelkie składniowe prawidła”, a „rozbioru logicznego autor uczy bardzo logicznie”. Artykuł podkreślał także ogólnie wysoki poziom publikacji wydawnictwa Ludwika Fiszera ${ }^{14}$.

Warto w tym miejscu zaznaczyć, że popularność tych podręczników wyznaczała liczba wydań. Na przestrzeni lat 1898-1913 Składnia miała 6 wydań, a Etymologia aż 11.

Po przedwczesnej śmierci założyciela księgarni, wydawanie podręczników szkolnych kontynuował, przy akceptacji wdowy, jej nowy zarządca Paweł Miks. Powoli podręczniki zaczęły zajmować czołowe miejsce pośród pozycji wydawniczych księgarni. Stało się to możliwe szczególnie po 1905 roku, za sprawą manifestu carskiego z 14 października, który zezwolił na zakładanie w Królestwie Polskim szkół prywatnych z polskim językiem wykładowym, oraz na wprowadzenie języka polskiego do szkół już istniejących. Sytuacja ta otworzyła nowe możliwości na rynku wydawniczym, bowiem oprócz już istniejących, zaczęto otwierać nowe placówki oświatowe, z możliwością nauczania w języku polskim. Również zmiany w programach szkolnych spowodowały rozszerzenie zakresu tematycznego podręczników, a co za tym idzie potrzebę publikacji nowych podręczników do wszystkich przedmiotów i zwiększanie ich nakładów.

14 „Rozwój” 1898, nr 230, s. 3. 
Intensywna działalność wydawnicza odpowiadała aktualnemu zapotrzebowaniu społecznemu, toteż z czasem księgarnia Ludwika Fiszera stała się najbardziej znaczącą firmą w Łodzi w zakresie wydawnictw podręcznikowych, a jej zarządca Paweł Miks wyrósł na najpoważniejszego producenta pomocy szkolnych w kraju.

Po 1900 roku wielokrotnie wznawiano publikowane wcześniej podręczniki do nauki języka niemieckiego i w języku niemieckim, zaspokajając w ten sposób potrzeby niemieckiej części łódzkiej społeczności Znalazł się wśród nich m.in. podręcznik do nauki j. niemieckiego pt. Lehrgang der deutschen Sprache Waldemara Osterloffa, który siedmiokrotnie wydawano w nakładzie 2-10 tys. egzemplarzy. Były drukowane także cieszące się dużym powodzeniem dwie książki autorstwa Alberta Ledera: Deutsches Lesebuch für mehrklassige Schulen i Deutsche Grammatik ${ }^{15}$.

Podręczników do nauki języka rosyjskiego w zasadzie firma L. Fiszera nie wydawała, bowiem zapotrzebowanie rosyjskiej części łódzkiej społeczności z powodzeniem wypełniały podręczniki wydawane na terenie Cesarstwa Rosyjskiego. Oficyna wydawnicza L. Fiszera wypuściła jedynie podręcznik opracowany przez J. M. Watsztejna Prakticzeskaja russkaja gramatyka oraz wydany w 1913 r. słownik rosyjsko-polski i polsko-rosyjski autorstwa J. Bohuszewicza.

Gdy zaś chodzi o podręczniki do nauki języków obcych, to m.in. staraniem wydawnictwa w 1906 r. wznowiono wydany wcześniej podręcznik Premières lectures et premièrem lecons de choses autorstwa Antoniego Mroczka oraz podręcznik dla szkół gimnazjalnych Rossmanna i Schmidta przeznaczony dla polskich uczniów. Również wydane w 1910 roku słowniki polsko-francuski i francusko-polski w opracowaniu Piotra Dahlmana cieszyły się na rynku dużym powodzeniem.

Ciekawostką mogą być tzw. samouczki, na które było spore zapotrzebowanie społeczne, a które były bardzo przydatne do nauki języków obcych. Wydawnictwo wyszło naprzeciw społecznym potrzebom, bowiem nakładem L. Fiszera takie wydawnictwa ukazały się pod tytułami: Polak we Francji (1906), Polak w Niemczech (1913) i Polak we Włoszech (1914).

Jednakże podstawą ugruntowanej pozycji oficyny wydawniczej L. Fiszer były wielokrotnie drukowane i wznawiane podręczniki do nauki języka polskiego.

Do wspomnianych wcześniej dwóch publikacji Władysława Kokowskiego należy dodać wydany w 1900 r. podręcznik dla szkół polskich Mój elementarz autorstwa Kazimierza Kędzierskiego. Publikacja cieszyła się dużą popularnością, tak że trzecie wydanie zostało rozszerzone i w 1905 r. ukazało się pod zmienionym tytułem Elementarz i książka do czytania ${ }^{16}$. O popularności tych wydawnictw niech świadczy fakt, że ich nakłady sięgały 12, a niekiedy i 15 tys. egzemplarzy ${ }^{17}$.

Materiałami uzupełniającymi i wspierającymi proces nauki języka polskiego - szczególnie w zakresie doskonalenia czytania, było wydane w 1901 r. Abecadło ruchome, pod postacią ruchomych literek do układania wyrazów i całych zdań, zaś Kurs kaligrafii polskiej, wydany dwukrotnie w roku 1906 i 1910, wspomagał trudną naukę pięknego pisania.

15 J. Jaworska, Łódzkie wydawnictwa..., s. 337.

16 Tamże, s. 336.

17 Tamże, s. 332. 
Pomocną, ale też rozszerzającą funkcję w procesie nauki języka polskiego na poziomie elementarnym pełniły Wypisy polskie o domu i świecie autorstwa wspomnianego już K. Kędzierskiego. Materiały te miały siedem wydań od 1906 do 1917 roku w nakładzie 5-7 tys. egzemplarzy. Publikacja zawierała głównie opowiadania i wiersze rozszerzające wiedzę dziecka o treści z zakresu geografii, historii, przyrody, ale za ich pomocą dziecko doskonaliło i utrwalało także poprawną pisownię i wymowę.

Materiałami uzupełniającymi do podręczników dla klas starszych autorstwa W. Kokowskiego były Słownik ortograficzny języka polskiego wydany po raz pierwszy w 1903 r. oraz Teoria literatury z 1904 r. i Ćwiczenia gramatyczne z 1905 r.

Ponieważ oficyna wydawnicza L. Fiszera drukowała podręczniki dla polskich szkół do wszystkich przedmiotów, nie możemy w tym miejscu ich pominąć, zwłaszcza że wykaz ich jest imponujący.

Wśród podręczników z zakresu matematyki najczęściej wydawano Zbiory zadań arytmetycznych Romualda Ciesielskiego. W latach 1906-1918 ukazało się ich 5 wydań po 2 tys. egzemplarzy każde. W 1907 roku wydano Zbiór zadań algebraicznych w zakresie programu gimnazjalnego w opracowaniu Tadeusza Jastrzębca. Drukowano także zbiory zadań innych autorów, jak: Zygmunta Rządkowskiego (1905), Bonifacego Wróblewskiego (1908) czy Antoniego Okraszewskiego (1906 i 1917).

Do grupy podręczników matematycznych zaliczyć należy również Algebrę elementarną Michała Feldbluma, wydaną w 1906 i 1907 roku, a także materiał pomocniczy w postaci Tablic logarytmicznych i trygonometrycznych Oskara Schlomilcha.

Podręczniki do nauki przyrody, geografii czy zoologii charakteryzował wysoki poziom edytorski. Najwcześniejszą publikacją z tego zakresu jest wydany jeszcze po rosyjsku w 1893 r. podręcznik J. S. Stejngauera Pierwyje uroki gieografii. Do 1914 roku wyszło kilka wydań tego podręcznika.

W 1905 roku już po polsku ukazała się nakładem wydawnictwa Geografia początkowa tajemniczego autora Stanisława J. Fakt ten odnotowała łódzka gazeta „Rozwój”, na łamach której czytamy: „nakładem Ludwika Fiszera (Warszawa-Łódź) wyszła w tłoczni F. M. Kulisza Geografia początkowa w opracowaniu Stanisława. Książka ta na 56 stronicach druku zawiera wiele rysunków, a w końcu posiada mapę dwóch półkuli i mapę Europy. W oprawie książka ta kosztuje 40 kop"18.

W 1906 roku wydano podręcznik do nauki przyrody autorstwa E. Skotnickiej pt. Kurs elementarny zoologii, botaniki, mineralogii, oraz Początki geografii K. Kędzierskiego. Pozycja ta do 1917 roku miała 4 wydania.

W 1907 roku ukazała się Geografia powszechna Alfreda Fuchsa.

Gdy zaś chodzi o pozycje z dziedziny zoologii, to niezwykle starannie w latach 1899-1900 wydano dwie publikacje z tego zakresu w opracowaniu C. H. Schuberta: Historię naturalną, która składała się z dwóch części: pierwsza to Zwierzęta ssące, zaś druga to Gady, oraz Historię naturalną ptaków ${ }^{19}$.

\footnotetext{
18 „Rozwój” 1906, nr 141, s. 2.

19 „Rozwój” 1907, nr 245, s. 3-4.
} 
Publikacje z zakresu historii stanowią dość skromny dorobek wydawnictwa. Fakt ten ma swoje uzasadnienie w trudnej ówcześnie sytuacji politycznej. Historia Polski jako przedmiot była niemożliwa do realizacji w polskich szkołach na terenie zaboru rosyjskiego, a same podręczniki do historii powszechnej przechodziły ostrą kontrolę carskiej cenzury, stąd nie było autorów, którzy chcieliby podjąć to trudne zadanie.

Po 1905 roku nakładem księgarni ukazały się jedynie Dzieje powszechne autorstwa W. Osterloffa i Józefa Szustera, wznawiane do 1914 r. aż 7 razy. W tym samym 1914 roku wydawnictwo wydało podręcznik przeznaczony dla młodszych dzieci Historię Polski, której autorem był S. Grobliński20.

Edukacyjny charakter miały także wydawnictwa adresowane do rzeszy łódzkich robotników w formie tanich książek i broszurek. Publikacje te, jako szczególnego rodzaju inicjatywy wydawnicze, pełniły wyjątkowe zadanie, a było nim popularyzowanie wiedzy wśród szerokich mas społeczeństwa miasta, szczególnie wśród klasy pracującej. Przykładem mogą tu być tzw. biblioteczki samokształceniowe, w ramach których specjaliści (lekarze, ekonomiści, społecznicy) redagowali poszczególne zeszyty, które stawały się krótkim poradnikiem z omawianego zakresu.

Wydawnictwo L. Fiszera włączyło się także w ten nurt, bowiem w ramach tzw. „Biblioteczki Społeczno-Ekonomicznej” nakładem oficyny ukazała się w 1911 r. broszura autorstwa Karola Forstera pt. Franklin jako przykład oszczędzania, Sheridan jako przykład marnotrawstwa, która miała za zadanie zainteresować łódzkich robotników ideą systematycznego gromadzenia pieniędzy ${ }^{21}$.

I wojna światowa i trwająca wraz z nią cztery lata okupacja miasta (a co za tym idzie brak zapotrzebowania na podręczniki i pomoce szkolne) przerwały niezwykle intensywną produkcję Oficyny Wydawniczej L. Fiszera. Jednak mimo załamania firma przetrwała i tuż po wojnie reaktywowała swoją działalność. Przez kolejną dekadę znów należała do najlepszych i najprężniejszych oficyn księgarsko-wydawniczych w mieście.

„Oficyna Wydawnicza Ludwik Fiszer” od początku swego istnienia do I wojny światowej wpisała się zasłużenie w walkę Polaków o narodowy charakter oświaty. Sprawa propagowania w jak najszerszym zakresie posługiwania się językiem polskim, popularyzowania dziejów ojczystych była dla wydawnictwa celem ważnym i uświadamianym. Dowodem mogą być wydawnictwa beletrystyczne adresowane do młodego i zarazem dojrzałego czytelnika o tematyce historycznej, jak również publikacje o podobnym charakterze udostępniane czytelnikowi w prowadzonej Wypożyczalni.

Fiszerowie jako przedstawiciele łódzkiej inteligencji odpowiedzieli aktywnie na odezwę, która ukazała się na łamach „Gońca Łódzkiego” w 1905 roku, w czasie rewolucyjnych działań na terenie miasta. Czytamy w niej: „...przerażająca moc analfabetów wśród mas ludowych, wytwór wiekowego ucisku [...] wkłada na barki obecnego pokolenia inteligencji naszej wielki a święty obowiązek możliwie

\footnotetext{
20 J. Jaworska, Łódzkie wydawnictwa..., s. 343

21 Tamże, s. 70.
} 
szybkiego zapełnienia olbrzymiej tej luki. [...] Żądamy i żądać będziemy - wraz ze wszystkimi postępowymi partiami - powszechnego, przymusowego, bezpłatnego państwowego nauczania elementarnego. A nim odnowione życie społeczne - po zwyciężeniu szalejącej obecnie anarchii - w nowej formie się wyleje [...], uważamy sobie za święty obowiązek wypowiedzieć walkę analfabetyzmowi. Stańmy się godnymi tych czasów, w jakich żyjemy, spełnijmy ten wielki obowiązek, jaki na nas wobec oświaty i kultury mas szerokich spoczywa. Wypowiedzmy walkę, potężną walkę analfabetyzmowi"22.

Fiszerowie byli w pełni świadomi, iż likwidacja analfabetyzmu w mieście, ale także na terenie Królestwa Polskiego, wiąże się z masową produkcją podręczników szkolnych. Swoją działalnością wydawniczą włączyli się aktywnie w ten proces, dość powiedzieć, że od 1882 do 1918 roku firma Ludwika Fiszera wydała ok. 400 tytułów (książek i broszur), zaś podręczniki szkolne stanowiły ponad $70 \%$ jej całego dorobku wydawniczego i $13 \%$ wszystkich druków łódzkich. Z uwagi więc na swój charakter firma, szczególnie po 1905 roku, realizowała konsekwentnie swoje zadanie, zyskując uznanie miejscowej prasy w zakresie wysokiego poziomu i staranności edytorskiej wydawanych podręczników ${ }^{23}$.

Niski poziom wyrobienia kulturalnego oraz niska skłonność do uczestnictwa w kulturze robotników łódzkich były także wyzwaniem dla Oficyny Ludwika Fiszera.

Wydawnictwo podejmowało próby i starania wpływania na kształt potrzeb czytelniczych społeczności miasta poprzez działalność o charakterze kulturalnym. Interesująca w tym względzie była wspomniana już inicjatywa podjęta przez Ludwika Fiszera seniora w 1899 r. wydania łódzkiego czasopisma literackiego "Ognisko Rodzinne".

W pierwszym numerze pismo niejako określiło profil adresata, do którego szczególnie chciało dotrzeć: „Lekarze, adwokaci, inżynierowie wydają pisma specjalistyczne dla swej sfery, lud wiejski ma swe pisma, ludzie wykształceni mają swoje pisma [...] pisane tak, by zrozumieć mogli, co się dzieje nowego w polityce, literaturze lub sztuce, ale poza tymi ludźmi jest zwłaszcza w Łodzi i jej okolicach cała masa klasy pracującej, która nie może czytać pism innych, bo są pisane mniej przystępnie i za dużo kosztują, a rwie się całą duszą do poznania wiedzy. Dla nich to, dla tych pracujących rozpoczynamy dziś nasze wydawnictwo"24.

Mimo iż pismo na rynku ukazywało się zaledwie rok, charakteryzowało się niezwykłą starannością edytorską, podkreślano również jego przystępny język. Ważne miejsce zajmowała w nim literatura piękna - proza i poezja. Na jego łamach zamieszczano wiersze, powieści i nowele autorów łódzkich (A. Gliszczyńskiego, A. Mogielnickiego i A. Warty), ale też wielkich i uznanych poetów, jak Maria Konopnicka, Juliusz Słowacki, a nawet Aleksander Puszkin. Pismo wprawdzie L. Fiszer wydawał zaledwie rok (do momentu swojej śmierci), jednak inicja-

22 Odezwa do inteligencji naszego miasta, „Goniec Łódzki” 1905, nr 298.

$23 \mathrm{~J}$. Konieczna dowodzi, iż recenzje i omówienia publikacji edukacyjno-pedagogicznych na łamach łódzkiej prasy tamtego okresu ukazywały się stosunkowo rzadko, tym bardziej należy docenić i zauważyć zainteresowanie prasy wydawnictwami L. Fiszera oraz ich niezwykle przychylny ton, por. J. Konieczna, Kultura książki polskiej w Łodzi przemysłowej (1820-1918), Łódź 2005, s. 277-288.

24 „Rozwój” 1905, nr 147, s. 2. 
tywa ta zdołała wpisać się znacząco w próby rozwijania potrzeb i zainteresowań czytelniczych łódzkich robotników.

Warto również podkreślić, jako cenną inicjatywę firmy, propozycję stałej prenumeraty czasopism, którą Księgarnia Fiszera adresowała szczególnie do łódzkiej inteligencji. Była to forma wprowadzenia stałego nawyku czytelniczego i przyzwyczajenia mieszkańców do systematyczności w czytaniu oraz dostępie do najbardziej aktualnej informacji z kraju i ze świata.

W lokalu Księgarni od początku jej istnienia mieściła się wspomniana już Wypożyczalnia, jako propozycja kontaktu z książką dla mniej zamożnych mieszkańców miasta. Z tej formy czytelnictwa korzystało z każdym rokiem coraz więcej czytelników. Książki wypożyczały osoby prywatne, m.in.: lekarze, adwokaci, przemysłowcy, ale także instytucje - typu stowarzyszenia o charakterze kulturalno-oświatowym oraz biblioteki szkolne.

Już w 1890 roku L. Fiszer wydał Katalog czytelni polskiej, francuskiej i angielskiej znajdującej się przy księgarni i składzie nut, zaś w 1909 roku wydano Katalog ruskich i niemieckich knig. Tym samym Księgarnia zadbała o reklamę i przybliżenie mieszkańcom oferty czytelniczej wypożyczalni nie tylko w języku polskim, ale też publikacji obcojęzycznych. Warto dodać, że podstawowy zasób księgozbioru stanowiła beletrystyka adresowana do dzieci i młodzieży.

W 1910 roku w jednym z artykułów w czasopiśmie „Rozwój” czytamy: „Wypożyczalnia książek w 5-ciu językach Księgarni Ludwika Fiszera przy ulicy Piotrkowskiej 48 została ogromnie powiększona. Zawiera wszelkie nowości beletrystyczne w języku polskim, rosyjskim, francuskim, niemieckim i angielskim. Przeszło 10000 tomów"25.

W artykule tym także podano zasady korzystania z wypożyczalni: abonament miesięczny na jedną książkę wynosił 1 rubel wraz z miesięczną opłatą 0,40 rb, na 2 książki 2 ruble i 0,75 rb opłaty, na 3 książki 2 ruble i opłata 1 rb, na 6 książek zaś abonament 4 ruble i opłata 1,60 rb. Wypożyczalnia działała w zasadzie przez cały okres aktywności oficyny, wpisując się tym samym pięknie w ciąg edukacyjnej aktywności wydawnictwa na rzecz miasta i jego mieszkańców.

Wszystkie wymienione tu obszary aktywności firmy „Oficyna Wydawnicza Ludwik Fiszer" świadczą niezbicie o patriotyzmie oraz wysokim stopniu zaangażowania właścicieli Wydawnictwa na rzecz rozwijania wrażliwości kulturalnej mieszkańców miasta Łodzi, a szczególnie, z uwagi na profil swojej działalności, rozbudzania potrzeby czytelnictwa w języku polskim. Aktywność wydawnictwa w procesie edycji podręczników i pomocy szkolnych wspierała przez lata trudny proces alfabetyzacji $75 \%$ nieznających dotąd liter mieszkańców miasta. Samo zaś wydawnictwo przez cały omawiany okres istnienia, oprócz prężnej działalności handlowej, pełniło rolę swoistego animatora życia kulturalnego, wnosząc znaczący wkład w rozwijanie intelektualnych i edukacyjnych potrzeb mieszkańców „polskiego Manchesteru”.

25 „Rozwój” 1910, nr 42, s. 8. 